PROCEEDINGS OF THE 5TH WFOT MEETING; 2016 NOV 18-20; MUMBAI, INDIA

\title{
Chronic kidney disease-CKD
}

\author{
Vipul J. Kakkad \\ BAMS, Private Practice. India.
}

\section{ABSTRACT}

OPEn ACCESS

\section{Citation}

Kakkad VJ. Chronic kidney disease-CKD [abstract]. Proceedings of the 5Th WFOT Meeting; 2016 Nov 18-20; Mumbai, India. J Ozone Ther. 2018;2(2). doi: 10.7203/jo3t. 2.2.2018.11154

\section{Academic Editor}

Jose Baeza-Noci,

School of Medicine, Valencia

University, SPAIN

\section{Editor}

World Federation of Ozone

Therapy, Bolgna, ITALY

\section{Received}

December 9, 2017

\section{Accepted}

December 10, 2017

\section{Published}

March 4, 2018

\section{Intellectual Property}

Vipul J. Kakkad. This is an open access article distributed under the terms of the Creative Commons Attribution License (CC BY 4.0), which permits unrestricted use, distribution, and reproduction in any medium, provided the original author and source are credited.

\section{Author Information}

drvipulkakkad@yahoo.com
Total Number of CKD patients treated with OZONE THERAPY (rectal or IV saline): 40 (Most of them are under the treatment of Nephrologists).

\section{Two categories:}

- Serum Creatine $<3$ (Stage 1-2-3) No. of pts. 23

- Serum Creatine $>3$ till 14 (Stage 4-5) No. of pts.17

1) Improvement observed for Stage 1-2-3 that is 1st category:

On the basis of Clinical evaluation \& Pathological criteria, $100 \%$ pts. improvement, with stable patho \& physiological criteria, for more than 18 months.

\section{2) Improvement observed for Stage 4-5 that is 2 nd category:}

- On the basis of Clinical evaluation \& Pathological criteria, $80 \%$ pts. Improved - Clinically \& Pathologically. (Stable for $>3$ months).

- No improvement was observed in $20 \%$ of pts.

$60 \%$ patients have shown Clinical \& Pathological improvement \& maintained for 6-12months.

$80 \%$ patients have shown Clinical \& Pathological improvement \& maintained for 3-6 months.

Clinical improvement as follows:

- Anorexia decreased, ,

- Sense of well-being improved,

- Energy level increased,

- Edema decreased,

- No changes in weight except +/- $1 \mathrm{~kg}$.

Pathological improvement:

- Hb improved

- Serum Creatinine \& Serum BUN reduction

- Proteinuria decreased

Ozone rectal insufflation are found to be more effective then IV ozone saline.

\section{CONCLUSION}

Patients who received rectal ozone continuously for more than 10 procedures are better improved and could maintain the improvement. 